\title{
A New Synthetic Route and Comprehensive Topological Study of a Benzimidazole Derivative
}

\author{
Vitor S. Duarte, ${ }^{\oplus *, a, b}$ Raquel F. Naves, ${ }^{c, d}$ Adailton J. Bortoluzzi, ${ }^{e}$ Eduardo C. M. Faria, ${ }^{a, b}$ \\ Aline M. da Silva, ${ }^{b}$ Guilherme R. Oliveira, ${ }^{c}$ Christian G. Alonso $^{\circledR c}{ }^{c}$ and \\ Hamilton B. Napolitano ${ }^{\circledR a}$ \\ ${ }^{a}$ Grupo de Química Teórica e Estrutural de Anápolis, Universidade Estadual de Goiás, \\ 75132-903 Anápolis-GO, Brazil \\ ${ }^{b}$ Centro de Pesquisa e Eficiência Energética, CAOA Montadora de Veículos LTDA, \\ 75133-590 Anápolis-GO, Brazil \\ 'Instituto de Química, Universidade Federal de Goiás, 74690-900 Goiânia-GO, Brazil \\ 'Instituto Federal de Goiás, Campus Inhumas, 75402-556 Inhumas-GO, Brazil \\ ${ }^{e}$ Departamento de Química, Universidade Federal de Santa Catarina, \\ 88040-900 Florianópolis-SC, Brazil
}

\begin{abstract}
Benzimidazole and its derivatives are molecules that have diverse biological properties, therefore we synthesized and studied a new benzimidazole to understand their physical/chemical properties. The compound was obtained through a new synthetic route, using graphite oxide, in the absence of solvent, with crystalline packaging supported by $\mathrm{C}-\mathrm{H} . . \mathrm{N}$ and $\mathrm{C}-\mathrm{H} . . . \pi$ interactions. According to the frontier molecular orbitals, the compound is kinetically stable while the molecular electrostatic potential map confirms the site of molecular interactions involving nitrogen atoms and the $\pi$-system. This comprehensive study on synthesis, structural description and theoretical calculations can support ongoing studies in pharmaceutical science.
\end{abstract}

Keywords: benzimidazole derivative, X-ray diffraction, supramolecular arrangement, QTAIM analysis

\section{Introduction}

Benzimidazole and its derivatives are widely studied due to their biological and clinical application. These compounds are heterocyclic formed from benzene and imidazole ring, and their structures are directly related to the planning and developing of drugs. The heteroaromatic bicyclic system of these compounds are described with biological activities, such as anti-inflammatory and anti-oxidant activity, ${ }^{1-3}$ antimicrobial activities (antifungal, antibacterial, antimalarial, antiviral activity), ${ }^{4,5}$ potential antitumor, ${ }^{6}$ antiprotozoal agents, ${ }^{7}$ anti-ulcer, anti-hypertensive and antiparkinson, ${ }^{8,9}$ analgesic agents and others activities. ${ }^{5,10}$

The chemical industry is an important provider of products and technologies for various pharmaceutical

*e-mail: vitor.sduarte@seduc.go.gov.br

Editor handled this article: José Walkimar M. Carneiro sectors, and other industries such as pesticides, foods, and fuel additives. When developing new chemical compounds for industrial areas there are some desirable criteria that must be met, such as having a synthesis in less than five steps with an acceptable yield, solubility and purity. ${ }^{11}$ Compounds that show a simple, low-cost, highyield synthetic route are certainly promising as industrial products, such as the synthesis of benzimidazole derivative described in this work, which is carried out in the absence of a solvent and presents interesting aspects. In addition to the biological potential consolidated in the literature, several systemic fungicides involving benzimidazoles are marketed, such as benomyl, ${ }^{12}$ thiophanate-methyl, ${ }^{13,14}$ carbendazim ${ }^{15}$ and carboxin ${ }^{16}$ while some commercial drugs involving different substituted benzimidazole derivatives also are used every day, such as thiabendazole, ${ }^{17}$ riluzole, omeprazole, lansoprazole, rabeprazole, and pantoprazole (Figure 1). 
<smiles>c1ccc2[nH]c(-c3cscn3)nc2c1</smiles>

Thiabendazole<smiles></smiles>

Riluzole

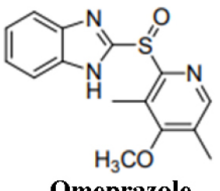

Omeprazole

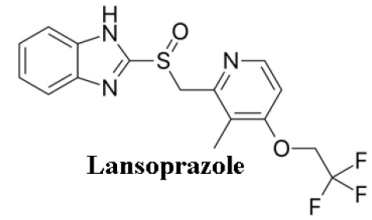<smiles>CC1=C(C(=O)Nc2ccccc2)C(C(C)(F)Cl)OCCS1</smiles><smiles>CCCCNC(=O)n1c(NC(=O)OC)nc2ccccc21</smiles>
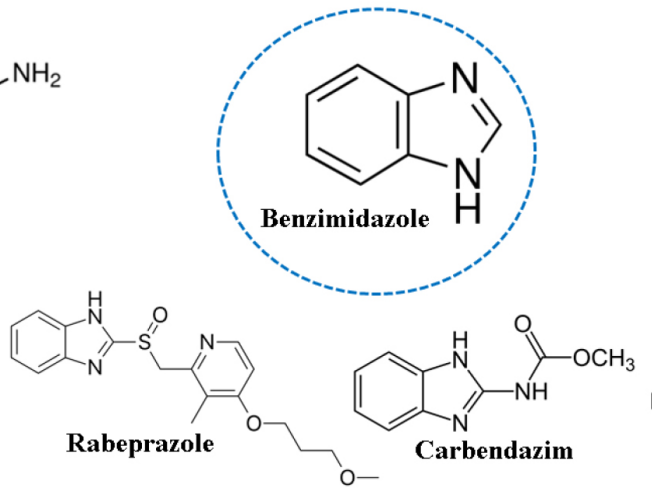

Thiophanate-methyl

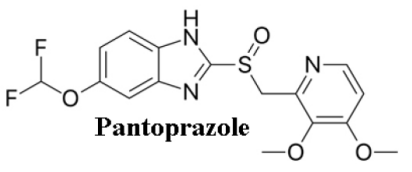

Figure 1. Benzimidazole core and some derived products.

The activity of a compound is linked to the chemical structure; therefore, studying this structure is extremely important, as well as understanding and developing more appropriate new synthetic routes. In this work we describe a new synthetic route for the 1-(2-methoxy-benzyl)2-(2-methoxy-phenyl)-2,3-dihydro- $1 H$-benzoimidazole (AM2), as well as its structural description, supramolecular arrangement analysis and theoretical calculations, to understand the physical/chemical properties of this compound and support ongoing application work in the pharmaceutical science.

\section{Experimental}

\section{Synthesis and crystallization}

In a round bottom flask, $o$-phenylenediamine (1 mmol) (1) and 2-methoxybenzaldehyde (2 mmol) (2) were stirred without solvent at $80{ }^{\circ} \mathrm{C}$ (Scheme 1). Then, $30 \mathrm{mg}$ of graphite oxide was added to the mixture. The mixture was stirred for $30 \mathrm{~min}$ and monitored by thin layer chromatography (TLC, hexane:ethyl acetate, 3:1). After its conclusion, ethanol was added $(10 \mathrm{~mL})$ and the mixture was filtered by gravitation of an analytical funnel, separating the graphite oxide of the obtained product. The compost was then washed with water $(5 \mathrm{~mL})$ three times and subsequently recrystallized with remaining ethanol $(10 \mathrm{~mL})$, obtaining a white yellowish crystal.

1-(2-Methoxy-benzyl)-2-(2-methoxy-phenyl)-2,3-dihydro$1 \mathrm{H}$-benzoimidazole (AM2)

Yield $86 \%$; yellowish crystal; mp $153-155{ }^{\circ} \mathrm{C} ;{ }^{1} \mathrm{H}$ $\left(500 \mathrm{MHz}, \mathrm{CDCl}_{3}\right) \delta 7.87(\mathrm{~d}, J 7.93 \mathrm{~Hz}, 1 \mathrm{H}), 7.56(\mathrm{dd}$,
$J 1.83$ and $7.63 \mathrm{~Hz}, 1 \mathrm{H}), 7.47$ (ddd, $J 1.83,7.63$ and $8.24 \mathrm{~Hz}, 1 \mathrm{H}), 7.29$ (ddd, $J 1.83,6.71$ and $8.24 \mathrm{~Hz}, 1 \mathrm{H}$ ), 7.24-7.19 (m, 3H), $7.07(\mathrm{td}, J 0.92,7.63$ and $7.63 \mathrm{~Hz}, 1 \mathrm{H})$, $6.98(\mathrm{~d}, J 8.24 \mathrm{~Hz}, 1 \mathrm{H}), 6.85(\mathrm{~d}, J 7.63 \mathrm{~Hz}, 1 \mathrm{H}), 6.78(\mathrm{td}$, $J 0.92,7.63$ and $7.63 \mathrm{~Hz}, 1 \mathrm{H}), 6.72(\mathrm{dd}, J 7.63$ and $1.53 \mathrm{~Hz}$, $1 \mathrm{H}), 5.26(\mathrm{~s}, 2 \mathrm{H}), 3.80(\mathrm{~s}, 3 \mathrm{H}), 3.61(\mathrm{~s}, 3 \mathrm{H}) ;{ }^{13} \mathrm{C}(500 \mathrm{MHz}$, $\left.\mathrm{CDCl}_{3}\right) \delta 157.6,156.5,154.4,143.3,135.5,132.4,131.4$, $128.4,127.7,124.5,122.4,121.9,120.8,120.4,119.8$, $110.8,110.7,109.9,55.2,55.1,43.5$.

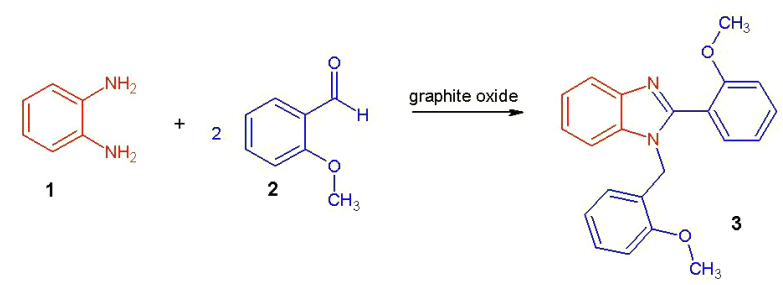

Scheme 1. Synthesis of AM2.

\section{Crystallographic and Hirshfeld analysis}

The model of the crystalline structure was determined by X-ray crystallography with data collected using a Bruker APEX-II CCD diffractometer (monochromator graphite Mo $\mathrm{K} \alpha$ radiation and $\lambda=0.71073 \AA$ ). The structure was solved by the SHELXT ${ }^{18,19}$ software and refined with ShelXL ${ }^{20-22}$ using full-matrix least-squares. The nonhydrogen atoms were refined with anisotropic thermal displacement parameters ${ }^{21}$ while hydrogen atoms were geometrically positioned and fixed according to the ridinghydrogen model with $0.98 \AA$ for methyl groups, $0.99 \AA$ for methylene groups and $0.95 \AA$ for aromatic groups. ${ }^{23}$ The molecular representations were generated by Olex $2,{ }^{24}$ CrystalExplorer ${ }^{25}$ and Mercury ${ }^{26}$ software. 
The intermolecular interactions for AM2 were analyzed using geometric parameters and confirmed by electronic density by Hirshfeld surfaces (HS) analysis using CrystalExplorer $17^{25}$ software. The Hirshfeld surfaces were generated from the X-ray data, representing the frontier between regions where the electron distribution is dominated by the contribution of the interior molecule and the neighboring. These surfaces are bases of the normalized contact distances $\left(\mathrm{d}_{\mathrm{e}}\right.$ : distance from the surface to the nearest atom in the molecule itself; $\mathrm{d}_{\mathrm{i}}$ : distance from the surface to the nearest atom in another molecule). ${ }^{27-29}$ In addition, the Hirshfeld analysis allows us to understand the quantitative of the interactions and the empty space in the crystalline structure. The fingerprint is a graph constructed from the distances of $\mathrm{d}_{\mathrm{e}}$ versus $\mathrm{d}_{\mathrm{i}}$ and indicates the quantitative contribution of the contacts present in the molecule. ${ }^{30}$ The empty spaces (voids) of the molecule were also calculated. To perform the calculations, the isosurfaces of the electron density of a procrystal equal to 0.002 a.u. were used. Said isosurface contains approximately $98 \%$ of the electrical charges of a molecule and determines the volume of the voids. ${ }^{31,32}$ Total crystallographic data for AM2 molecule was deposited in the Cambridge Crystallographic Data Centre (CCDC) ${ }^{33}$ under the code 2091809.

\section{Computational procedures}

Theoretical calculations for AM2 were carried out using density functional theory (DFT) ${ }^{34}$ through experimental parameters obtained from the X-ray data. The geometry was optimized in the gas phase using the Gaussian $09^{35}$ software. The level of theory used was M06-2X/6-311++G(d,p). ${ }^{36-38}$ This level of theory considering the electronic correlation, ${ }^{39,40}$ and is indicated for noncovalent interactions. ${ }^{36,41}$ From the results and generated wave function, the frontier molecular orbitals (FMO), the molecular electrostatic potential map (MEP) and topological analysis by quantum theory of atoms in molecules (QTAIM) were done. In order to identify the reactive regions of the AM2 molecule, the MEP calculation was performed; this map is constructed based on the potential of atomic nuclei and electrons, according to the equation:

$\mathrm{V}(\mathbf{r})=\sum_{\alpha} \frac{\mathrm{Z}_{\mathrm{A}}}{\left|\mathrm{r}_{\alpha}-\mathrm{r}_{\mathrm{A}}\right|}-\int \frac{\rho(\mathrm{r})}{\mathrm{r}_{\alpha}-\mathrm{r}} \mathrm{dr}$

where, $\mathrm{Z}_{\mathrm{A}}$ is the charge on nucleus $\alpha, \mathrm{V}(\mathbf{r})$ is a potential created at a point $\mathbf{r}$ and the first term of summation is the electrostatic potential created by the nucleus. The second term is the electrostatic potential created by electrons. ${ }^{42}$
The topological analysis were carried out by QTAIM methodology that is based on the mechanical-quantum concepts. ${ }^{43-46} \mathrm{Bader}^{44,45}$ developed a theory that describes the atomic behavior in a molecule. In this theory, the observable properties are present in its molecular electron density $\rho(\mathbf{r})$. From this density, numerical integrations are executed with the gradient vector $\nabla \rho(\mathbf{r})$. These observables allow us to define chemical bonding as a bonding path (BP) which has a critical point $(\mathrm{CP})$ that through defined parameters can indicate the existence of an interaction. ${ }^{45,47}$ For topological analysis of the interactions, the generated wave function was loaded into the Multiwfn ${ }^{48}$ software.

\section{Results and Discussion}

\section{Synthesis and solid-state description}

The synthesis for AM2 occurs in the presence of different conditions, obtaining yields above $85 \%$. Graphite oxide, a carbonaceous compound with acidic sites, is used as a catalyst for the synthesis of AM2. Thus, AM2 occurs in the absence of solvent, occurring at $80{ }^{\circ} \mathrm{C}$, and within a time interval of $60 \mathrm{~min}$. Therefore, obtaining AM2 in the presence of graphite oxide presents a simple synthetic route in the absence of solvent and being recrystallized only with ethanol. According to the geometric parameters of the unit cell, the AM2 crystallized under monoclinic space group $\mathrm{P} 2_{1} / \mathrm{c}$ with two molecules in the asymmetric unit and eight molecules in the unit cell. AM2 compound presents 2 methoxy groups in each molecule, both in the ortho position. All this data was obtained by X-ray diffraction and elucidated by the crystallographic methodology (Table 1) and Oak Ridge Thermal-Ellipsoid Plot (ORTEP) representation for this molecule is presented in Figure 2.

The asymmetric unit of AM2 has two molecules, however, conformer $\mathbf{1}$ does not overlap with conformer $\mathbf{2}$ (Figure 3). The conformers have a torsion in the aromatic ring regions $\mathrm{A}, \mathrm{A}^{\prime}$ and $\mathrm{C}, \mathrm{C}^{\prime}$. Aromatic ring $\mathrm{A}$ from conformer 1 has a difference of $78.43^{\circ}$ to aromatic ring $\mathrm{A}^{\prime}$ from conformer $\mathbf{2}$, while aromatic ring $\mathrm{C}$ from conformer $\mathbf{1}$ has a difference of $42.72^{\circ}$ to aromatic ring C' from conformer 2.

The supramolecular arrangement of AM2 is stabilized only by weak interactions, such $\mathrm{C}-\mathrm{H} \cdots \mathrm{N}$ and $\mathrm{C}-\mathrm{H} \cdots \pi$ (Figure 4). However, these interactions have been described by several authors as significant in crystal packing. ${ }^{49-59}$ The interactions $\mathrm{C} 18-\mathrm{H} 18 \cdots \mathrm{N} 2, \mathrm{C} 1-\mathrm{H} 1 \mathrm{c} \cdots \mathrm{N} 2, \mathrm{C} 1{ }^{\prime}-\mathrm{H} 1 \mathrm{a}^{\prime} \cdots \mathrm{N} 2$ ' and $\mathrm{C}^{\prime}-\mathrm{H} 3^{\prime} \cdots \mathrm{N} 2$ ' contributing to growth of the crystal in the [001] direction, while the $\mathrm{C} 5-\mathrm{H} 5 \cdots \mathrm{CgB}$ ' interaction contributed to [010] direction and $\mathrm{C} 17-\mathrm{H} 17 \cdots \mathrm{CgC}$ and 

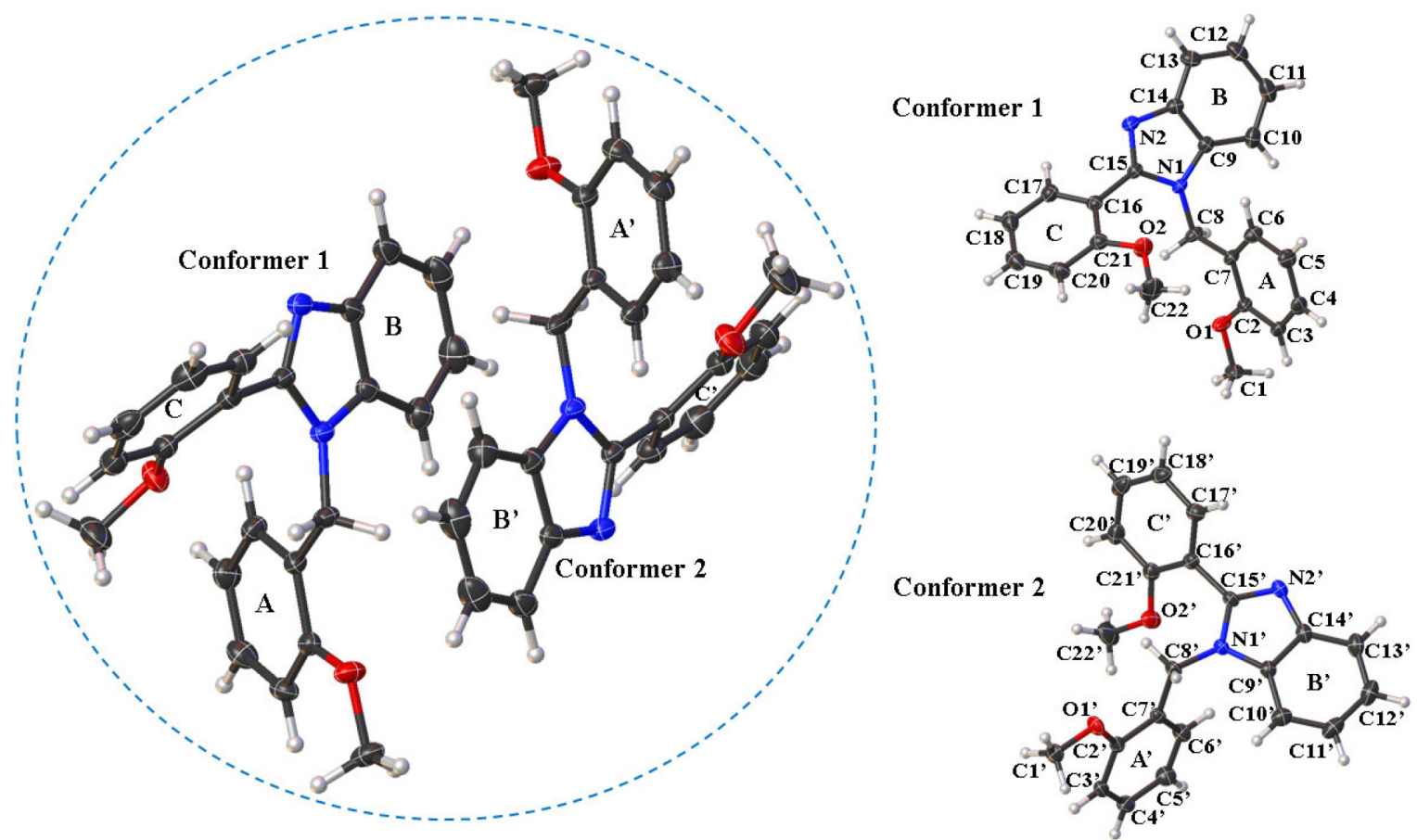

Figure 2. ORTEP representation of AM2 with ellipsoids at $50 \%$ of probability.

Table 1. Crystallographic refinement data for AM2

\begin{tabular}{|c|c|}
\hline Molecular formula & $\left(\mathrm{C}_{22} \mathrm{H}_{20} \mathrm{~N}_{2} \mathrm{O}_{2}\right)_{2}$ \\
\hline Formula weight $/\left(\mathrm{g} \mathrm{mol}^{-1}\right)$ & 344.40 \\
\hline Temperature / K & $150(2)$ \\
\hline Wavelength / $\AA$ & 0.71073 \\
\hline Radiation type & Mo K $\alpha$ \\
\hline Crystal system, space group, Z & monoclinic, $\mathrm{P} 2_{1} / \mathrm{c}, 8$ \\
\hline Unit cell dimensions / $\AA$ & $\begin{array}{c}\mathrm{a}=19.5627(17) \\
\mathrm{b}=10.3557(8) \\
\mathrm{c}=20.1999(18)\end{array}$ \\
\hline Unit cell dimensions / degree & $\begin{array}{c}\alpha=90 \\
\beta=118.87(2) \\
\gamma=90\end{array}$ \\
\hline Volume / $\AA^{3}$ & $3583.3(5)$ \\
\hline Calculated density / $\left(\mathrm{g} \mathrm{m}^{-3}\right)$ & 1.277 \\
\hline Absorption coefficient $/ \mathrm{mm}^{-1}$ & 0.083 \\
\hline $\mathrm{F}(000)$ & 1456 \\
\hline Refinement method & full-matrix least-squares on $F^{2}$ \\
\hline Goodness-of-fit on $\mathrm{F}^{2}$ & 1.042 \\
\hline $\begin{array}{l}\text { Final } R \text { indices }[\mathrm{I}>2 \sigma(\mathrm{I})] \\
\mathrm{R} \text { indices (all data) }\end{array}$ & $\begin{array}{l}R_{1}=0.0521 ; \mathrm{w} R_{2}=0.1211 \\
R_{1}=0.0818 ; \mathrm{w} R_{2}=0.1391\end{array}$ \\
\hline
\end{tabular}

$\mathrm{C} 1-\mathrm{H} 1 \mathrm{~b} \cdots \mathrm{CgC}$ interactions contributed to [010] and [100] directions. The data of these interactions is shown in Table 2.

The interactions of AM2 were characterized from the geometric parameters with X-ray data and confirmed from the electronic density by HS analysis. The interactions involving $\mathrm{H} \cdots \mathrm{N}$ are shown in Figure $4 \mathrm{a}$ and confirmed by HS dnorm (Figure $4 \mathrm{~b}$ ). In this surface, red spots indicate the regions where interactions can occur. Represented intermolecular contacts are smaller than the sum of van der Waal radius ( $\mathrm{vdW})$. According to the geometric parameters the $\mathrm{C} 18-\mathrm{H} 18 \cdots \mathrm{N} 2$ and $\mathrm{C} 3^{\prime}-\mathrm{H} 3^{\prime} \cdot \cdots \mathrm{N} 2{ }^{\prime}$ interactions present the shorter distances $[\mathrm{d}(\mathrm{H} \cdots \mathrm{A}), \mathrm{d}(\mathrm{D} \cdots \mathrm{A}) \AA]$ and the HS dnorm analysis of the regions (1) and (4) indicate stronger interactions.

The $\mathrm{C}-\mathrm{H} \cdots \pi$ interactions presented in AM2 also contributed to crystal packing, despite their weak nature $\left(1.0-2.5 \mathrm{kcal} \mathrm{mol}^{-1}\right) .^{60-64}$ These interactions were described by geometric parameters and confirmed by HS shape index (Figure 5), in which blue convex regions on $\mathrm{C}-\mathrm{H}$ atoms and red concave regions on aromatic rings systems indicate the location of these interactions. ${ }^{28,29}$ In the Figure $5 \mathrm{a}$ the $\mathrm{C} 17-\mathrm{H} 17 \cdots \mathrm{CgC}$ and $\mathrm{C} 1-\mathrm{H} 1 \mathrm{~b} \cdots \mathrm{CgB}$ ' interactions are confirmed by blue convex region over the atoms C17-H17 while red concave region over aromatic ring $\mathrm{CgC}$. Additionally, Figure $5 \mathrm{~b}$ evidences the $\mathrm{C} 5-\mathrm{H} 5 \cdots \mathrm{CgC}$ interaction with blue convex region over the atoms $\mathrm{C} 5-\mathrm{H} 5$ and red concave region over aromatic ring $\mathrm{CgB}$ '.

From the characterization of the interactions present for the stability of AM2, we performed the percentage quantification of the contribution of these interactions. For this analysis, the fingerprint is able to indicate the percentage of each interaction presented in the molecule. In the 2D-fingerprint plot for the AM2 (Figure 6a), the presence 

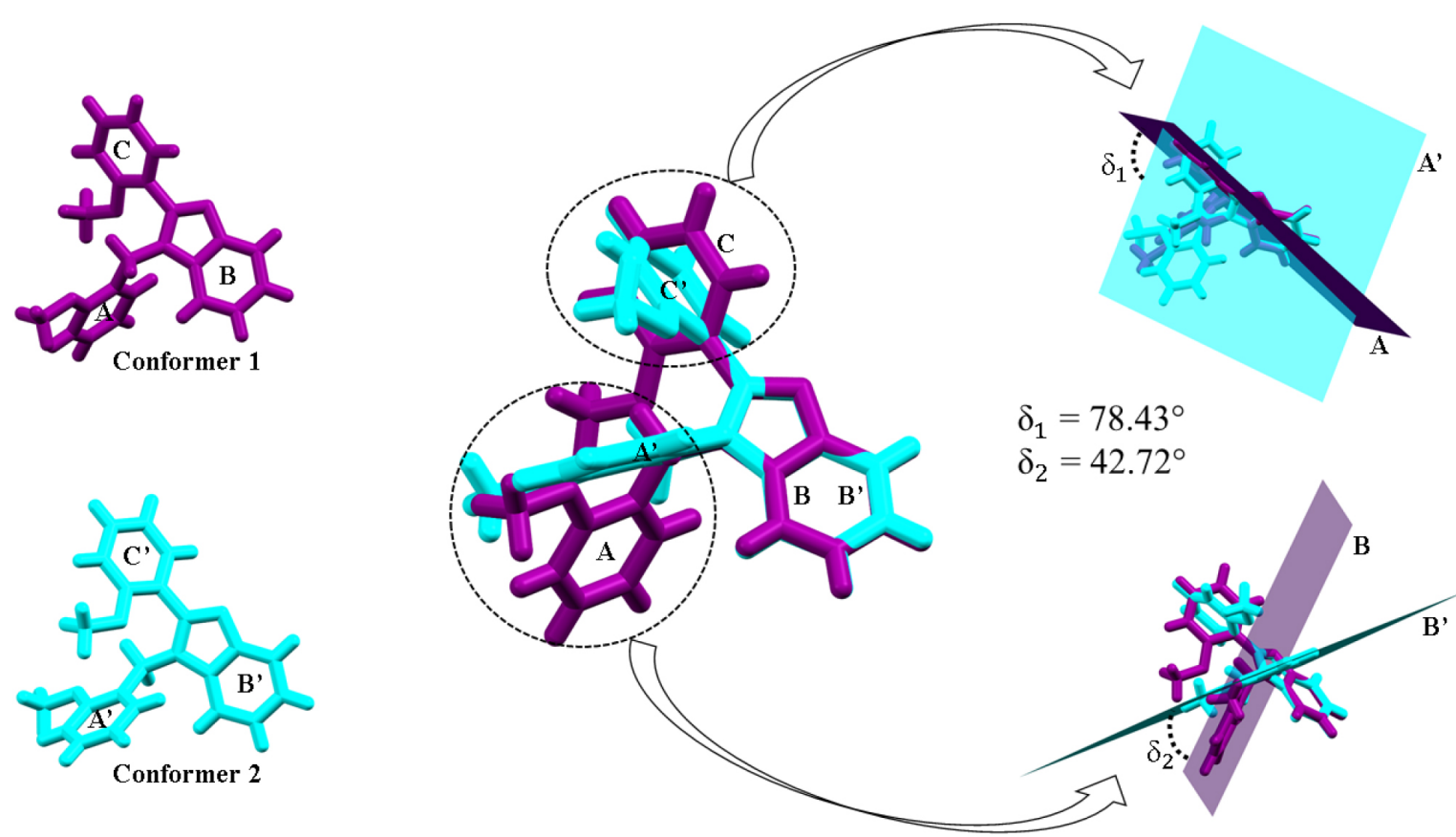

Figure 3. Overlap between conformers $\mathbf{1}$ and $\mathbf{2}$ of AM2.

Table 2. Observed interactions for AM2

\begin{tabular}{lccccc}
\hline $\mathrm{D}-\mathrm{H} \cdots \mathrm{A}$ & $\mathrm{d}(\mathrm{D}-\mathrm{H}) / \AA$ & $\mathrm{d}(\mathrm{H} \cdots \mathrm{A}) / \AA$ & $\mathrm{d}(\mathrm{D} \cdots \mathrm{A}) / \AA$ & $\mathrm{d}(\mathrm{D}-\mathrm{H} \cdots \mathrm{A}) /$ degree & Symmetry code \\
\hline $\mathrm{C}^{\prime}{ }^{\prime}-\mathrm{H}{ }^{\prime} \cdots \mathrm{N} 2$ & & 2.586 & 3.459 & 152.95 & $\mathrm{x}, 1 / 2-\mathrm{y}, 1 / 2+\mathrm{z}$ \\
$\mathrm{C}{ }^{\prime}-\mathrm{H} 1 \mathrm{a}^{\prime} \cdots \mathrm{N}{ }^{\prime}$ & 0.950 & 2.657 & 3.407 & 133.63 & $\mathrm{x}, 1 / 2-\mathrm{y}, 1 / 2+\mathrm{z}$ \\
$\mathrm{C} 18-\mathrm{H} 18 \cdots \mathrm{N} 2$ & 0.980 & 2.568 & 3.451 & 154.73 & $\mathrm{x}, 3 / 2-\mathrm{y}, 1 / 2+\mathrm{z}$ \\
$\mathrm{C} 1-\mathrm{H} 1 \mathrm{c} \cdots \mathrm{N} 2$ & 0.950 & 2.742 & 3.522 & 136.91 & $\mathrm{x}, 3 / 2-\mathrm{y}, 1 / 2+\mathrm{z}$ \\
$\mathrm{C} 1-\mathrm{H} 1 \mathrm{~b} \cdots \mathrm{CgB}{ }^{\prime}$ & 0.980 & 3.253 & 4.221 & 169.99 & $-\mathrm{x}, 1-\mathrm{y}, 1-\mathrm{z}$ \\
$\mathrm{C} 5-\mathrm{H} 5 \cdots \mathrm{CgC}$ & 0.980 & 3.310 & 3.886 & 121.06 & $\mathrm{x}, 3 / 2-\mathrm{y}, 1 / 2+\mathrm{z}$ \\
$\mathrm{C} 17-\mathrm{H} 17 \cdots \mathrm{CgC}$ & 0.950 & 3.616 & 4.373 & 138.52 & $-\mathrm{x},-1 / 2+\mathrm{y}, 1 / 2-\mathrm{z}$ \\
\hline
\end{tabular}

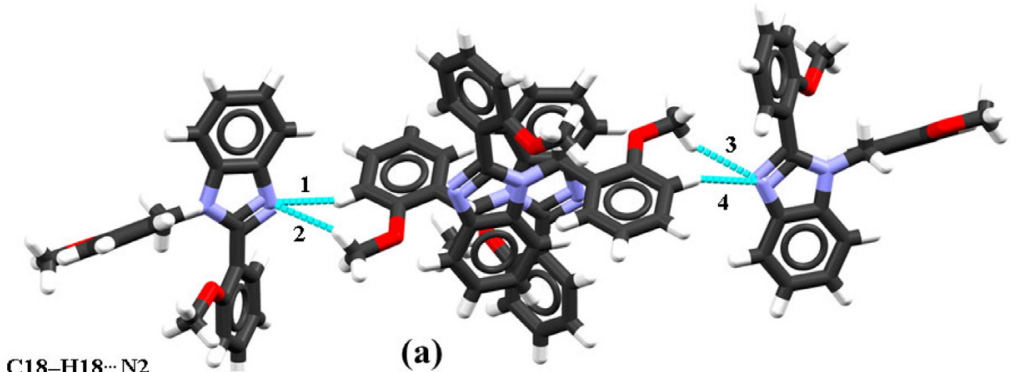

(1) $\mathrm{C} 18-\mathrm{H} 18 \cdots \mathrm{N} 2$
(2) $\mathrm{C} 1-\mathrm{H} 1 \mathrm{c}^{\cdots} \cdot \mathrm{N} 2$
(3) $\mathrm{C} 1 \mathrm{~N}^{-}-\mathrm{H}^{\prime} \cdot \cdots \mathrm{N} 2$
(4) $\mathrm{C} 3{ }^{\prime}-\mathrm{H}^{\prime} \cdots \mathrm{N} 2$

(a)

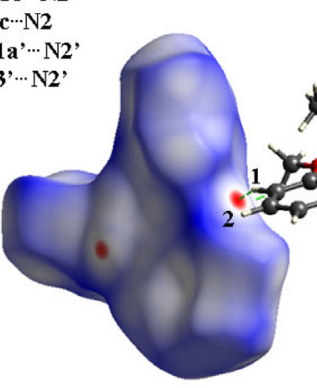

(b)

Figure 4. Representation of the interactions presents in AM2. 

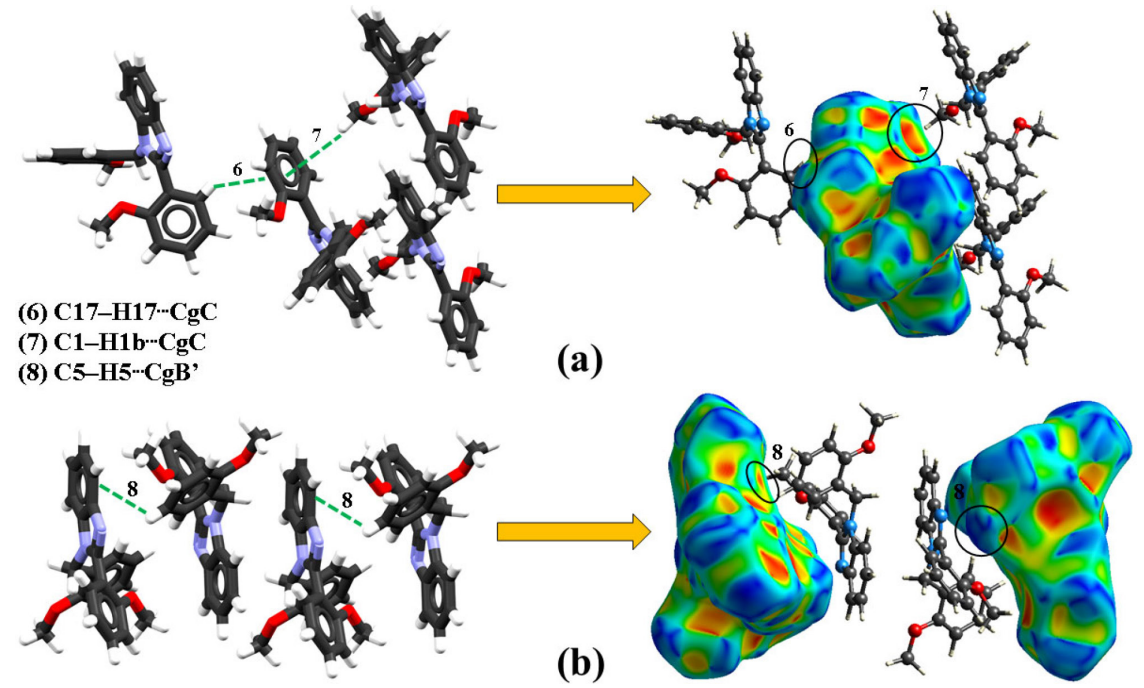

Figure 5. HS shape index of the $\mathrm{C}-\mathrm{H} \cdots \pi$ interactions presented in AM2.

of pseudo-mirrored peaks in region $1.0\left(\mathrm{~d}_{\mathrm{e}}, \mathrm{d}_{\mathrm{i}}\right)-1.2\left(\mathrm{~d}_{\mathrm{e}}, \mathrm{d}_{\mathrm{i}}\right)$ indicate contacts involving hydrogens $(\mathrm{H} \cdot \cdots \mathrm{H})$ representing $62.1 \%$ of contacts in AM2. Additionally, $1.4\left(\mathrm{~d}_{\mathrm{e}}\right)$ with $1.0\left(\mathrm{~d}_{\mathrm{i}}\right)$ and $1.4\left(\mathrm{~d}_{\mathrm{i}}\right)$ with $1.0\left(\mathrm{~d}_{\mathrm{i}}\right)$ indicate $\mathrm{C}-\mathrm{H} \cdots \mathrm{N}$ interactions $(\mathrm{H} \cdots \mathrm{N})$ corresponding to $6.4 \%$ whereas $\mathrm{C}-\mathrm{H} \cdots \pi$ interactions, which are represented by $\mathrm{H} \cdots \mathrm{C}$, are $26.9 \%$ of the interactions. These interactions represented $95.4 \%$ of the total structural stability of AM2. The packing of the crystalline structure presents eight molecules in the unit cell. Figure 6b shows the packing of the unit cell and the voids. These voids correspond to the empty space existing in the crystalline structure and were calculated from the electronic density of the spherical atom model. The calculated volume of the voids was $439.11 \AA^{3}$, corresponding to approximately $12.25 \%$ of the unit cell. Note that there is little empty space in AM2; there are no large cavities, and the electrondensity iso-surfaces are not completely closed around the

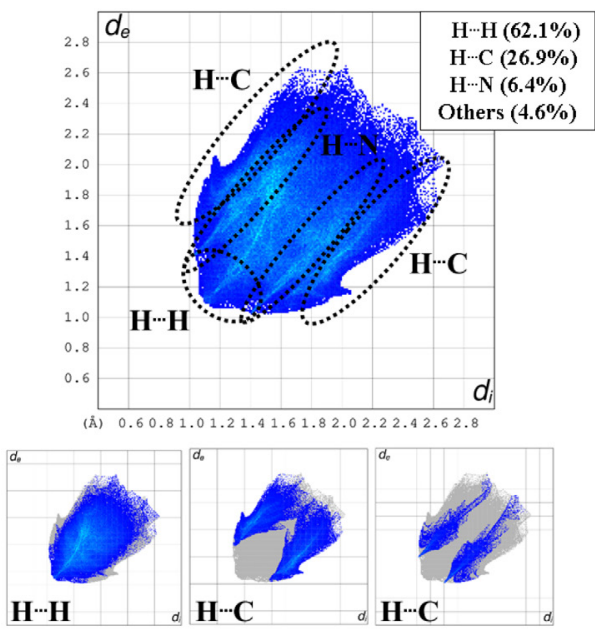

(a) components, being open in the regions that molecular interactions are found, e.g., $\mathrm{C}-\mathrm{H} \cdots \mathrm{N}$ and $\mathrm{C}-\mathrm{H} \cdots \pi$.

Molecular modeling analysis

The highest occupied molecular orbital (HOMO) orbital for AM2 is located on aromatic rings B and C (conformer 1) or B' and C' (conformer 2) while lowest unoccupied molecular orbital (LUMO) orbital is located close to the aromatic ring A (conformer 1) and aromatic ring A' (conformer 2) (Figure 7). The LUMO orbitals are characterizing $\pi^{*}$ antibonding, their energies are negative confirmed that these regions are electrophilic subject to accept electrons in a chemical reaction, while HOMO orbital characterizing nonbonding orbital, which is characteristic of the nucleophilic region. ${ }^{65,66}$ The GAP energy, defined as GAP $=\mathrm{E}_{\mathrm{LUMO}}-\mathrm{E}_{\mathrm{HOMO}}$, is an important

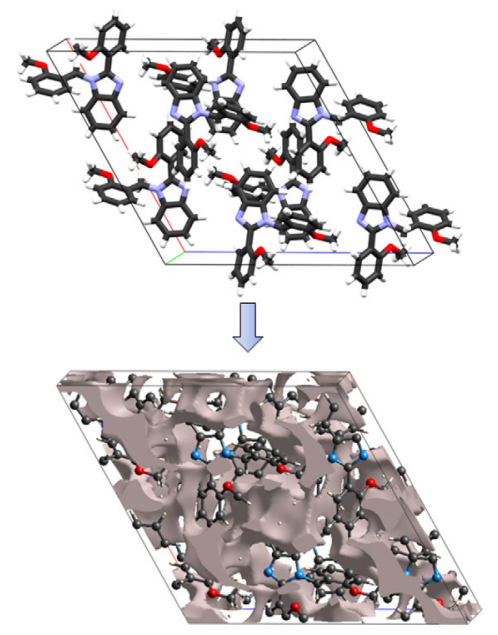

(b)

Figure 6. Fingerprint with quantitative of the contacts for AM2 (a). Packing of the unit cell and the voids presents in AM2 (b). 

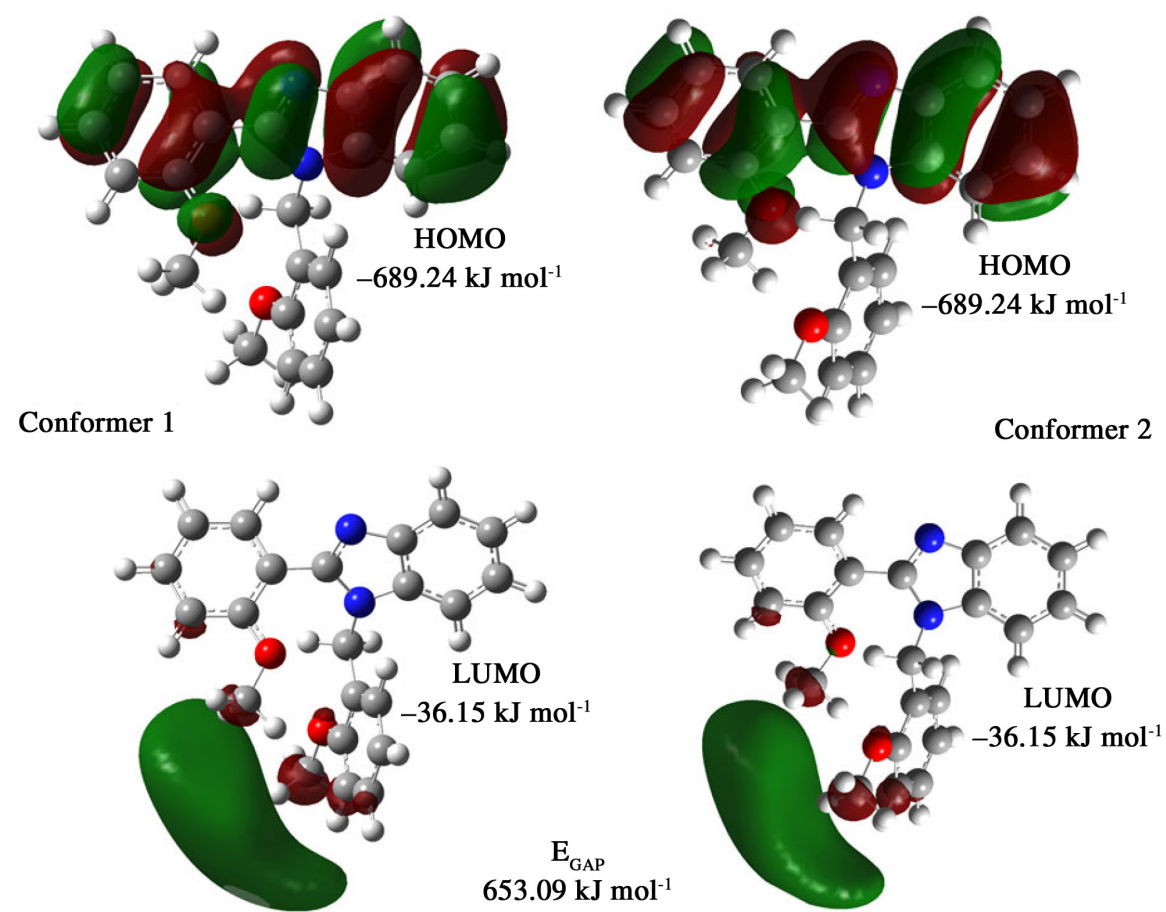

Figure 7. Frontier molecular orbitals (HOMO/LUMO) for AM2.

indicator of the kinetic stability and chemical reactivity of the molecule. ${ }^{66}$ High GAP values suggest high kinetic stability and high excitation energies, whereas low GAP values suggest high chemical reactivity. ${ }^{66}$ The energy GAP calculated for AM2 is $653.09 \mathrm{~kJ} \mathrm{~mol}^{-1}$. According to said parameter, in comparison with same class molecules, ${ }^{67-81}$ AM2 is presented kinetically stable.

In the MEP map (Figure 8) blue colors (positive values) indicate regions susceptible to electrophilic attacks due to the low electron density while red colors (negative values) indicate regions susceptible to nucleophilic attack due to the high electron density. ${ }^{42,82,83}$ On the N2 and N2' atoms, conformer $\mathbf{1}$ and 2, respectively, the MEP energy is about $-160 \mathrm{~kJ} \mathrm{~mol}^{-1}$ for both. According to this interpretation, the nitrogen sites of AM2 susceptible to nucleophilic

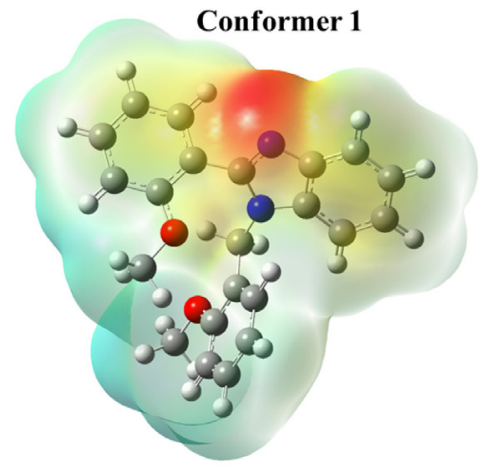

$-160.05 \mathrm{~kJ} \mathrm{~mol}^{-1}$ attack, correspond to the $\mathrm{C}^{\prime}-\mathrm{H} 3^{\prime} \cdot \cdots \mathrm{N} 2^{\prime}, \mathrm{C} 1^{\prime}-\mathrm{H} 1 \mathrm{a}^{\prime} \cdot \mathrm{N} 2^{\prime}$, $\mathrm{C} 18-\mathrm{H} 18 \cdots \mathrm{N} 2$ and $\mathrm{C} 1-\mathrm{H} 1 \mathrm{c} \cdots \mathrm{N} 2$ interactions described by geometrical parameters and electronic density. The aromatic rings $\mathrm{B}$ and $\mathrm{C}$ (conformer $\mathbf{1}$ ) and $\mathrm{B}^{\prime}$ and $\mathrm{C}^{\prime}$ (conformer 2) have MEP energy at about $-8.53 \mathrm{~kJ} \mathrm{~mol}^{-1}$ (aromatic rings $\mathrm{B}$ and $\mathrm{B}$ ) and $-7.74 \mathrm{~kJ} \mathrm{~mol}^{-1}$ (aromatic rings $\mathrm{C}$ and $\mathrm{C}^{\prime}$ ) which corresponds to the locations of the $\mathrm{C} 1-\mathrm{H} 1 \mathrm{~b} \cdots \mathrm{CgB}$, C $5-\mathrm{H} 5 \cdots \mathrm{CgC}$ and $\mathrm{C} 17-\mathrm{H} 17 \cdots \mathrm{CgC}$ interactions. The regions of nucleophilic attack can be ranked as follows: N2 and N2' $>$ aromatic ring B and $\mathrm{B}^{\prime}>$ aromatic ring $\mathrm{C}$ and $\mathrm{C}^{\prime}$.

The QTAIM analysis provided insights of the $\mathrm{C}-\mathrm{H} \cdots \mathrm{N}$ interactions investigating the properties of bonding critical point $(\mathrm{BCP})$. These properties are electron density $\rho(\mathbf{r})$ at critical point, Laplacian of electron density $\nabla^{2} \rho(\mathbf{r})$,

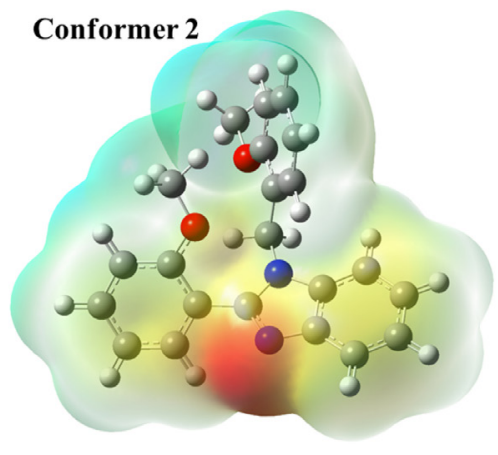

$160.05 \mathrm{~kJ} \mathrm{~mol}^{-1}$

Figure 8. MEP map for AM2. 
eigenvalues of Hessian matrix $\left(\lambda_{1}, \lambda_{2}\right.$ and $\left.\lambda_{3}\right)$, ellipticity of electron density $(\varepsilon)$, potential electron energy density $\mathrm{V}(\mathbf{r})$, kinetic electron energy density $\mathrm{G}(\mathbf{r})$ and energy density $\mathrm{H}(\mathbf{r})$, as shown in Table 3. QTAIM analysis has been used to describe a series of interactions (dihydrogen bonding, ${ }^{84-88} \mathrm{C}-\mathrm{H} \cdots \mathrm{O}$ interactions ${ }^{89-93}$ and classical hydrogen bondings, ${ }^{94-97}$ halogen bondings, ${ }^{98-105}$ $\pi$-systems interactions, ${ }^{106-108}$ interactions involving Se atoms ${ }^{109,110}$ and $\mathrm{C}-\mathrm{H} \cdots \mathrm{N}$ interactions). ${ }^{11-116}$ According to Popelier and $\mathrm{Koch}^{84,90}$ and others authors ${ }^{117,118}$ some criteria in the QTAIM analysis are necessary to characterize an interaction, such as a continuous density path with a critical point $(\mathrm{CP})$ between acceptor and donor atoms, electron density $\rho(\mathbf{r})$ in the critical point in range of $0.002-0.035$ a.u and $\nabla^{2} \rho(\mathbf{r})$ in range of $0.024-0.139$ a.u. All the $\mathrm{C}-\mathrm{H} \cdots \mathrm{N}$ interactions of AM2 analyzed have a continuous density path between donor and acceptor atoms, as well as the presence of a CP between them (Figure 9). The values of $\rho(\mathbf{r})$ in the CP for all interactions are in the expected range, as are the values of values of $\nabla^{2} \rho(\mathbf{r})$, except for interaction C1'-H1a' '..N2' (0.02045 a.u.), which has a slight deviation.

The indicators $\nabla^{2} \rho(\mathbf{r})>0$ and $\mathrm{H}(\mathbf{r})>0$ suggest that the analyzed interactions are weak interactions with closed-shell character. ${ }^{46,118}$ The ellipticity $(\varepsilon=\lambda 1 / \lambda 2-1)$ is defined as a measure of the anisotropy of the curvature of the $\rho(\mathbf{r})$ and the extent to which the charge is preferentially accumulated, and can be used to investigate about the structural stability of a bond. ${ }^{90,119}$ The order of ellipticity for these interactions is $\varepsilon\left(\mathrm{C}^{\prime}-\mathrm{H} 1 \mathrm{a}^{\prime} \cdots \mathrm{N} 2^{\prime}\right)>$ $\varepsilon(\mathrm{C} 1-\mathrm{H} 1 \mathrm{c} \cdots \mathrm{N} 2)>\varepsilon(\mathrm{C} 18-\mathrm{H} 18 \cdots \mathrm{N} 2)>\varepsilon\left(\mathrm{C}^{\prime}-\mathrm{H} 3^{\prime} \cdot \cdots \cdot \cdot \mathrm{N} 2^{\prime}\right)$. In terms of ellipticity $\mathrm{C} 1{ }^{\prime}-\mathrm{H} 1 \mathrm{a}^{\prime} \cdots \mathrm{N} 2$ ' and $\mathrm{C} 18-\mathrm{H} 18 \cdots \mathrm{N} 2$ interactions are harder to be broken than $\mathrm{C} 18-\mathrm{H} 18 \cdots \mathrm{N} 2$ and $\mathrm{C} 3^{\prime}-\mathrm{H} 3^{\prime} \cdot$...N2'. All these characteristics and parameters contribute to confirm the existence of these interactions.

\section{Structure comparison}

In the literature, we find a polymorph (Mol-2) ${ }^{120}$ and the same structural form (Mol-1) ${ }^{121}$ for AM2. Figure 10 shows the comparison between the 3 molecules. The polymorph (Mol-2) has a different conformation, with one molecule in the asymmetric unit and four in the unit cell, besides different unit cell parameters. The cell angles for Mol-2 are $\alpha=90^{\circ}, \beta=91.06(10)^{\circ}$ and $\gamma=90^{\circ}$, note that, these angles are very different from the AM2 molecule, the $\beta$ angle $\left(91.06^{\circ}\right)$ of Mol-2 is close to $90^{\circ}$, almost characterizing Mol-2 in a different crystalline system, such as the orthorhombic $\left(a \neq b \neq c ; \alpha=\beta=\gamma=90^{\circ}\right)$. In addition, the packaging of the Mol-2 polymorph differs greatly from the AM2 packaging, driven by different interactions and the empty spaces (voids) between the molecules is similar, around $12 \%$.

The graphite oxide was used as a catalyst for the synthesis of AM2 whereas it is Mol-1 and Mol-2 molecules. The reaction takes place in the absence of catalyst, but uses methanol, dichloromethane and triethylamine as solvent.

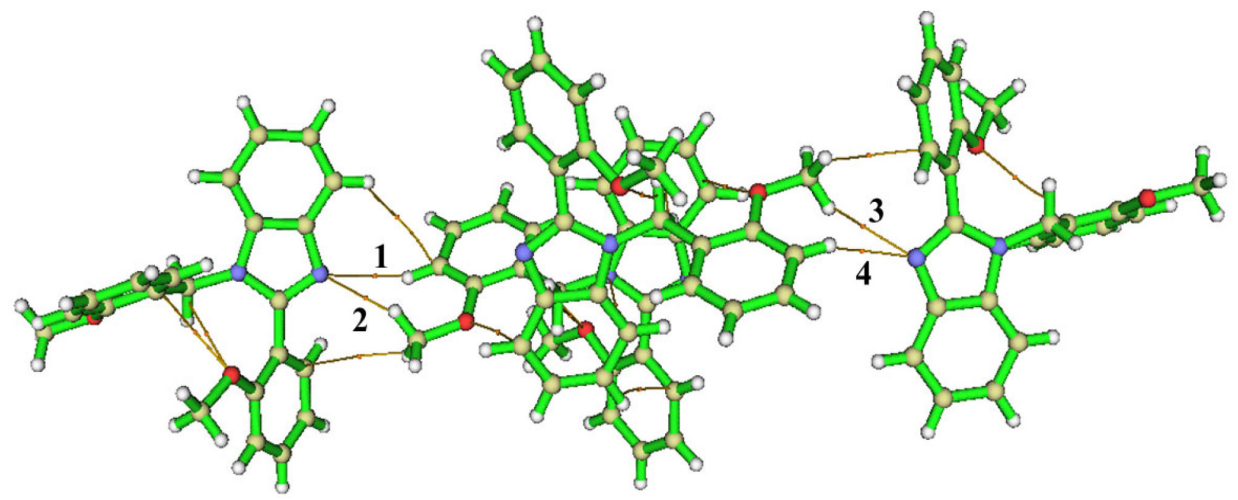

Figure 9. Critical points for $\mathrm{C}-\mathrm{H} \cdots \mathrm{N}$ interactions of AM2.

Table 3. Data from the topological analysis performed by the QTAIM methodology for AM2

\begin{tabular}{lcccccccccc}
\hline BCP & $\rho(\mathbf{r}) /$ a.u. & $\nabla^{2} \rho(\mathbf{r}) /$ a.u. & $\lambda_{1} /$ a.u. & $\lambda_{2} /$ a.u. & $\lambda_{3} /$ a.u. & $\varepsilon /$ a.u. & $\mathrm{V}\left(\mathbf{r}_{\text {bcp }}\right) /$ a.u. & $\mathrm{G}\left(\mathbf{r}_{\text {bcp }}\right) /$ a.u. & $\mathrm{H}(\mathbf{r}) /$ a.u. & Interactions \\
\hline 1 & 0.00864 & 0.02686 & -0.00723 & -0.00692 & 0.04101 & 0.04499 & -0.00443 & 0.00557 & 0.00114 & $\mathrm{C} 18-\mathrm{H} 18 \cdots \mathrm{N} 2$ \\
2 & 0.00824 & 0.02507 & -0.00677 & -0.00605 & 0.03790 & 0.11841 & -0.00438 & 0.00532 & 0.00094 & $\mathrm{C} 1-\mathrm{H} 1 \mathrm{c} \cdots \mathrm{N} 2$ \\
3 & 0.00698 & 0.02045 & -0.00545 & -0.00486 & 0.03077 & 0.12092 & -0.00368 & 0.00439 & 0.00071 & $\mathrm{C} 1^{\prime}-\mathrm{H} 1 \mathrm{a}^{\prime} \cdots \mathrm{N} 2^{\prime}$ \\
4 & 0.00900 & 0.02810 & -0.00766 & -0.00736 & 0.04313 & 0.04036 & -0.00459 & 0.00580 & 0.00121 & $\mathrm{C} 3^{\prime}-\mathrm{H} 3^{\prime} \cdots \mathrm{N}{ }^{\prime}{ }^{\prime}$ \\
\hline
\end{tabular}

QTAIM: quantum theory of atoms in molecules; a.u.: atomic units (Hartree atomic units). A hartree is equal to $2625.5 \mathrm{~kJ} \mathrm{~mol}^{-1}, 627.5 \mathrm{kcal} \mathrm{mol}^{-1}, 27.211 \mathrm{eV}^{2}$ and $219474.6 \mathrm{~cm}^{-1}$. BCP: bonding critical point; $\rho(\mathbf{r})$ : electron density at critical point; $\nabla^{2} \rho(\mathbf{r})$ : Laplacian of electron density; $\lambda_{1}, \lambda_{2}$ and $\lambda_{3}$ : eigenvalues of Hessian matrix; $\varepsilon$ : ellipticity of electron density; $\mathrm{V}(\mathbf{r})$ : potential electron energy density; $\mathrm{G}(\mathbf{r})$ : kinetic electron energy density; $\mathrm{H}(\mathbf{r})$ : energy density. 


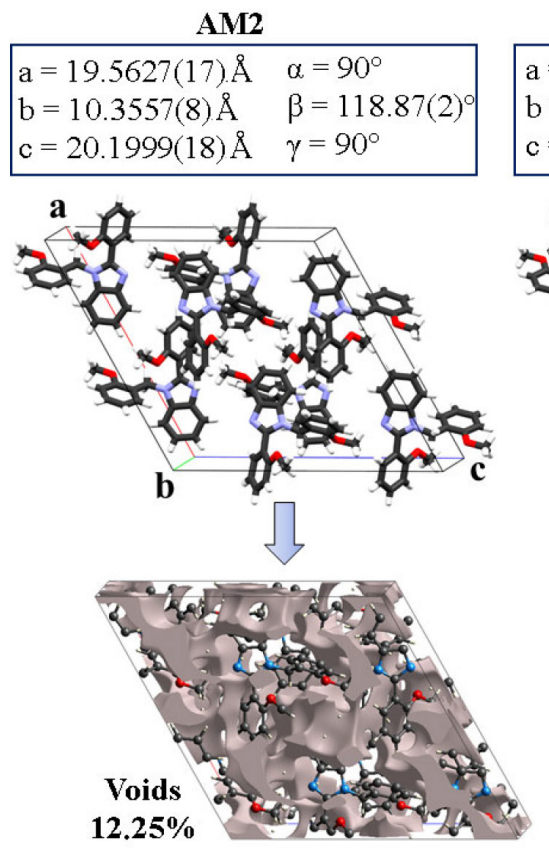

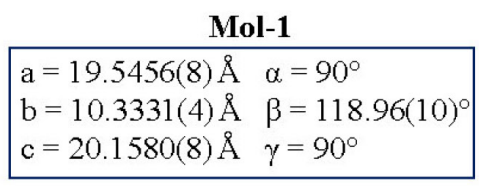
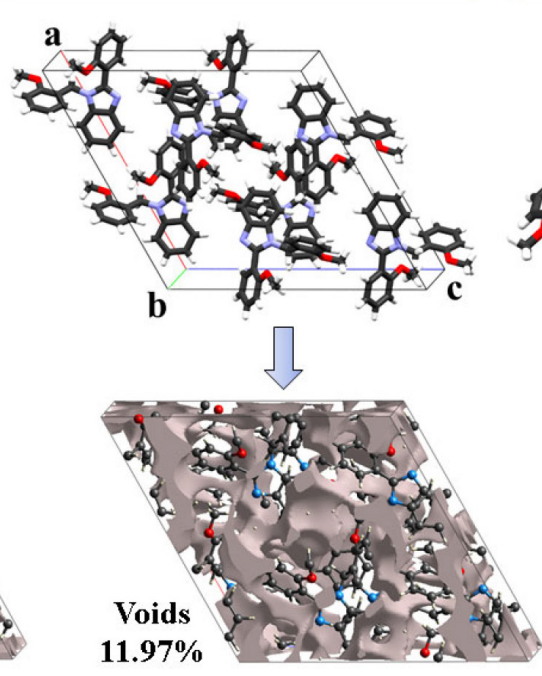

Mol-2

\begin{tabular}{|ll|}
\hline $\mathrm{a}=9.6638(2) \AA$ & $\alpha=90^{\circ}$ \\
$\mathrm{b}=10.4904(2) \AA$ & $\beta=91.06(10)^{\circ}$ \\
$\mathrm{c}=18.0444(3) \AA$ & $\gamma=90^{\circ}$ \\
\hline
\end{tabular}
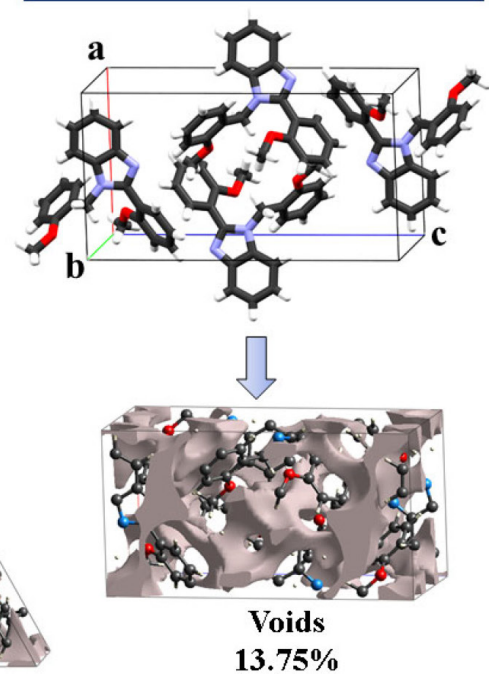

Figure 10. Comparison between AM2, Mol-1 and Mol-2.

The AM2 synthesis occurs in the absence of solvent within a time interval of $60 \mathrm{~min}$, while molecules Mol-1 and Mol-2 use solvent and were obtained during a minimum interval of $3 \mathrm{~h}$. The AM2 synthetic route in the presence of graphite oxide is simple and environmentally viable-considering it occurs $(i)$ in a shorter reaction time, (ii) in the absence of solvents and (iii) in the presence of ethanol only when recrystallized.

\section{Conclusions}

The AM2 compound was obtained through a new synthetic route, by using graphite oxide in the absence of solvent, occurring at $80{ }^{\circ} \mathrm{C}$, and within a time interval of 60 min. AM2 crystallized in monoclinic space group $\mathrm{P}_{1} / \mathrm{c}$ with two molecules in the asymmetric unit, and its supramolecular arrangement is supported by $\mathrm{C}-\mathrm{H} \cdots \mathrm{N}$ and $\mathrm{C}-\mathrm{H} \cdots \pi$ interactions. These interactions described by geometric parameters, were confirmed by electron density and QTAIM topological analysis. Molecular orbitals indicated kinetic stability and the potential map confirmed the interaction sites. All these descriptions corroborate to understand this class of molecule and contribute to future application studies on pharmaceutical industry. Also, the described interactions observed unto supramolecular arrangement can be explored in the context of biological activities, as well as in the identification of the active sites responsible for electrophilic (or nucleophilic) attacks. Finally, these comprehensive structural aspects can be linked on structure-property relations in the biological scope.

\section{Supplementary Information}

Crystallographic data (excluding structure factors) for the structures in this work were deposited in the Cambridge Crystallographic Data Centre as supplementary publication number CCDC 2091809. Copies of the data can be obtained, free of charge, via https://www.ccdc.cam. ac.uk/structures/.

Supplementary information ( ${ }^{1} \mathrm{H}$ NMR spectrum and ${ }^{13} \mathrm{C}$ NMR spectrum of compound AM2) is available free of charge at http://jbcs.sbq.org.br as PDF file.

\section{Acknowledgments}

This research was developed with the support of the Brazilian agencies Fundação de Amparo à Pesquisa do Estado de Goiás (FAPEG), Conselho Nacional de Desenvolvimento Científico e Tecnológico (CNPq) and Coordenação de Aperfeiçoamento de Pessoal de Nível Superior (CAPES). The authors thank the High Performance Computing Center of the Universidade Estadual de Goiás (UEG).

\section{Author Contributions}

V. S. Duarte and H. B. Napolitano were responsible for conceptualization, investigation, data curation and project administration; R. F. Naves, G. R. Oliveira and C. G. Alonso for experimental syntheses and characterization of substances; A. J. Bortoluzzi for investigation, X-ray crystallography data treatment, software and validation; E. C. M. Faria, A. M. da Silva 
for conceptualization, visualization and formal analysis funding acquisition. All authors were responsible for writing original draft ad writing-review and editing.

\section{References}

1. Kosolapov, V. A.; Spasov, A. A.; Anisimova, V. A.; Zhukovskaya, O. N. In Antioxidants; Shalaby, E., ed.; IntechOpen, 2019, DOI: 10.5772/intechopen.82817.

2. Rajasekaran, S.; Gopalkrishna, R.; Chatterjee, A.; Int. J. Drug Dev. Res. 2012, 4, 303.

3. Mavrova, A. T.; Yancheva, D.; Anastassova, N.; Anichina, K.; Zvezdanovic, J.; Djordjevic, A.; Markovic, D.; Smelcerovic, A.; Bioorg. Med. Chem. 2015, 23, 6317.

4. Singh, N.; Pandurangan, A.; Rana, K.; Anand, P.; Ahamad, A.; Tiwari, A. K.; Int. Curr. Pharm. J. 2012, 1, 110.

5. Fei, F.; Zhou, Z.; Expert Opin. Ther. Pat. 2013, 23, 1157.

6. Salahuddin; Shaharyar, M.; Mazumder, A.; Arabian J. Chem. 2017, 10, S157.

7. Patel, V. M.; Patel, N. B.; Chan-Bacab, M. J.; Rivera, G.; Synth. Commun. 2020, 50, 858.

8. Khosravi, K.; Kazemi, S.; Chin. Chem. Lett. 2012, 23, 61.

9. Bachhav, H. M.; Bhagat, S. B.; Telvekar, V. N.; Tetrahedron Lett. 2011, 52, 5697.

10. Keri, R. S.; Hiremathad, A.; Budagumpi, S.; Nagaraja, B. M.; Chem. Biol. Drug Des. 2015, 86, 19.

11. Katsuno, K.; Burrows, J. N.; Duncan, K.; van Huijsduijnen, R. H.; Kaneko, T.; Kita, K.; Mowbray, C. E.; Schmatz, D.; Warner, P.; Slingsby, B. T.; Nat. Rev. Drug Discovery 2015, 14 , 751.

12. Hauptmann, R. M.; Widholm, J. M.; Paxton, J. D.; Plant Cell Rep. 1985, 4, 129.

13. Australian Pesticide and Veterinary Medicines Authority (APVMA); Thiophanate-Methyl Final Review Report and Regulatory Decision, 2010, available at https://apvma.gov.au/ sites/default/files/publication/14826-thiophanate-methyl-finalreport.pdf, accessed in October 2021.

14. United States Environmental Protection Agency (USEPA); Thiophanate-Methyl and Carbendazim (MBC); available at https://archive.epa.gov/pesticides/reregistration/web/pdf/ tm_red.pdf, accessed in October 2021.

15. Carbendazim, https://echa.europa.eu/registration-dossier/-/ registered-dossier/27856/1/1, accessed in October 2021.

16. de Bittencourt, S. R. M.; Menten, J. O. M.; Araki, C. A. S.; de Moraes, M. H. D.; Rugai, A. R.; Dieguez, M. J.; Vieira, R. D.; Rev. Bras. Sementes 2007, 29, 214.

17. Rosenblum, C.; Meriwether, H. T.; J. Radioanal. Chem. 1970, $6,379$.

18. Girolami, G. S.; Brumaghim, J. L.; Priepot, J. G.; Govei, J. P.; A Guide to Using SHELXTL; available at https://scs.illinois.edu/ system/files/inline-files/shelxtl_nt.pdf, accessed in October 2021.
19. Sheldrick, G. M.; Acta Crystallogr., Sect. A: Found. Adv. 2015, 71,3 .

20. Sheldrick, G. M.; Gilmore, C. J.; Hauptman, H. A.; Weeks, C. M.; Millerc R.; Usón, I.; Int. Tables Crystallogr. 2012, 16, 428.

21. Sheldrick, G. M.; Acta Crystallogr. Sect. A 2008, 64, 112.

22. Muller, P.; Herbst-Irmer, R.; Spek, A. L.; Schneider, T. R.; Sawaya, M. R.; Crystal Structure Refinement - A Crystallographer's Guide to SHELXL, $1^{\text {st }}$ ed.; Muller, P., ed.; Oxford University Press: New York, 2006.

23. Lübben, J.; Volkmann, C.; Grabowsky, S.; Edwards, A.; Morgenroth, W.; Fabbiani, F. P. A.; Sheldrick, G. M.; Dittrich, B.; Acta Crystallogr., Sect. A: Found. Adv. 2014, 70, 309.

24. Dolomanov, O. V.; Bourhis, L. J.; Gildea, R. J.; Howard, J. A. K.; Puschmann, H. J.; J. Appl. Crystallogr. 2009, 42, 339.

25. Wolff, S. K.; Grimwood, D. J.; McKinnon, J. J.; Turner, M. J.; Jayatilaka, D.; Spackman, M. A.; CrystalExplorer17; University of Western Australia, 2012.

26. Macrae, C. F.; Edgington, P. R.; McCabe, P.; Pidcock, E.; Shields, G. P.; Taylor, R.; Towler, M.; Van De Streek, J.; J. Appl. Crystallogr. 2006, 39, 453.

27. McKinnon, J. J.; Spackman, M. A.; Mitchell, A. S.; Acta Crystallogr., Sect. B: Struct. Sci. 2004, 60, 627.

28. McKinnon, J. J.; Jayatilaka, D.; Spackman, M. A.; Chem. Commun. 2007, 3814.

29. Spackman, M. A.; Jayatilaka, D.; CrystEngComm 2009, 11, 19.

30. Spackman, M. A.; McKinnon, J. J.; CrystEngComm 2002, 4, 378.

31. Turner, M. J.; McKinnon, J. J.; Jayatilaka, D.; Spackman, M. A.; CrystEngComm 2011, 13, 1804.

32. Dalal, J.; Sinha, N.; Yadav, H.; Kumar, B.; RSC Adv. 2015, 1, 38.

33. Groom, C. R.; Bruno, I. J.; Lightfoot, M. P.; Ward, S. C.; Acta Crystallogr., Sect. B: Struct. Sci., Cryst. Eng. Mater. 2016, B72, 171.

34. Burke, K.; J. Chem. Phys. 2012, 136, 150901.

35. Frisch, M. J.; Trucks, G. W.; Schlegel, H. B.; Scuseria, G. E.; Robb, M. A.; Cheeseman, J. R.; Scalmani, G.; Barone, V.; Mennucci, B.; Petersson, G. A.; Nakatsuji, H.; Caricato, M.; Li, X.; Hratchian, H. P.; Izmaylov, A. F.; Bloino, J.; Zheng, G.; Sonnenberg, J. L.; Hada, M.; Ehara, M.; Toyota, K.; Fukuda, R.; Hasegawa, J.; Ishida, M.; Nakajima, T.; Honda, Y.; Kitao, O.; Nakai, H.; Vreven, T.; Montgomery Jr., J. A.; Peralta, J. E.; Ogliaro, F.; Bearpark, M.; Heyd, J. J.; Brothers, E.; Kudin, K. N.; Staroverov, V. N.; Kobayashi, R.; Normand, J.; Raghavachari, K.; Rendell, A.; Burant, J. C.; Iyengar, S. S.; Tomasi, J.; Cossi, M.; Rega, N.; Millam, J. M.; Klene, M.; Knox, J. E.; Cross, J. B.; Bakken, V.; Adamo, C.; Jaramillo, J.; Gomperts, R.; Stratmann, R. E.; Yazyev, O.; Austin, A. J.; Cammi, R.; Pomelli, C.; Ochterski, J. W.; Martin, R. L.; Morokuma, K.; Zakrzewski, V. G.; Voth, G. A.; Salvador, P.; Dannenberg, J. J.; Dapprich, S.; Daniels, A. D.; Farkas, Ö.; 
Foresman, J. B.; Ortiz, J. V.; Cioslowski, J.; Fox, D. J.; Gaussian 09, Revision A.01; Gaussian, Inc., Wallingford, CT, USA, 2009.

36. Zhao, Y.; Truhlar, D. G.; Theor. Chem. Acc. 2008, 120, 215.

37. Krishnan, R.; Binkley, J. S.; Seeger, R.; Pople, J. A.; J. Chem. Phys. 1980, 72, 650.

38. McLean, A. D.; Chandler, G. S.; J. Chem. Phys. 1980, 72, 5639.

39. Wiberg, K. B.; J. Comput. Chem. 2004, 25, 1342.

40. Sousa, S. F.; Fernandes, P. A.; Ramos, M. J.; J. Phys. Chem. A 2007, 111, 10439.

41. Hohenstein, E. G.; Chill, S. T.; Sherrill, C. D.; J. Chem. Theory Comput. 2008, 4, 1996.

42. Sjoberg, P.; Politzer, P.; J. Phys. Chem. 1990, 94, 3959.

43. Hilal, R.; Aziz, S. G.; Alyoubi, A. O.; Elroby, S.; Procedia Comput. Sci. 2015, 51, 1872.

44. Bader, R. F. W.; J. Chem. Phys. 1989, 91, 6989.

45. Bader, R. F. W.; Acc. Chem. Res. 1985, 18, 9.

46. Biegler-könig, F. W.; Bader, R. F. W.; Tang, T.; J. Comput. Chem. 1982, 3, 317.

47. Bader, R. F. W.; Chem. Rev. 1991, 91, 893.

48. Lu, T.; Chen, F.; J. Comput. Chem. 2012, 33, 580.

49. Taylor, R.; Cryst. Growth Des. 2016, 16, 4165.

50. Nuermaimaiti, A.; Ning, Y.; Cramer, J. L.; Svane, K. L.; Hammer, B.; Gothelf, K. V.; Linderoth, T. R.; Langmuir 2017, 33,10782 .

51. Peng, Y.; Feng, Y.; Deng, G.-J.; He, Y.-M.; Fan, Q.-H.; Langmuir 2016, 32, 9313.

52. Desiraju, G. R.; Chem. Commun. 2005, 2995.

53. Favero, L. B.; Giuliano, B. M.; Maris, A.; Melandri, S.; Ottaviani, P.; Velino, B.; Caminati, W.; Chem.- Eur. J. 2010, $16,1761$.

54. Alshahateet, S. F.; Bishop, R.; Craig, D. C.; Scudder, M. L.; Cryst. Growth Des. 2004, 4, 837.

55. Langley, P. J.; Hulliger, J.; Thaimattam, R.; Desiraju, G. R.; New J. Chem. 1998, 22, 1307.

56. Zhang, Z.; Luo, Y.; Chen, J.; Dong, S.; Yu, Y.; Ma, Z.; Huang, F.; Angew. Chem., Int. Ed. 2011, 50, 1397.

57. Hong, Y. J.; Tantillo, D. J.; Chem. Sci. 2013, 4, 2512.

58. Munshi, P.; Guru Row, T. N.; Crystallogr. Rev. 2005, 11, 150.

59. Sureshan, K. M.; Gonnade, R. G.; CrystEngComm 2013, 15, 1676.

60. Takagi, T.; Tanaka, A.; Matsuo, S.; Maezaki, H.; Tani, M.; Fujiwara, H.; Sasaki, Y.; J. Chem. Soc., Perkin Trans. 2 1987, 1015.

61. Singh, N. J.; Min, S. K.; Kim, D. Y.; Kim, K. S.; J. Chem. Theory Comput. 2009, 5, 515.

62. Tsuzuki, S.; Honda, K.; Uchimaru, T.; Mikami, M.; Fujii, A.; J. Phys. Chem. A 2006, 110, 10163.

63. Tsuzuki, S.; Honda, K.; Uchimaru, T.; Mikami, M.; Tanabe, K.; J. Am. Chem. Soc. 2000, 122, 3746.

64. Tsuzuki, S.; Fujii, A.; Phys. Chem. Chem. Phys. 2008, 10, 2584.
65. Grant, G. H.; Richards, W. G.; Computational Chemistry; Oxford University Press: Oxford, 1996.

66. Pereira, D. H.; la Porta, F. A.; Santiago, R. T.; Garcia, D. R.; Ramalho, T. C.; Rev. Virtual Quim. 2016, 8, 425.

67. Chakib, I.; Elmsellem, H.; Sebbar, N. K.; Lahmidi, S.; Nadeem, A.; Essassi, E. M.; Ouzidan, Y.; Abdel-Rahman, I.; Bentiss, F.; Hammouti, B.; J. Mater. Environ. Sci 2016, 7, 1866.

68. Chen, T.-R.; J. Mol. Struct. 2005, 737, 35.

69. Yang, L.; Wang, F.; Sun, Z.; Kong, X.; Kong, Y.; Anal. Methods 2020, $12,3123$.

70. Mol, G. P. S.; Aruldhas, D.; Bull. Pure Appl. Sci. Chem. 2018 , $37 c, 20$.

71. Yeh, A.; Mater. Lett. 2005, 59, 1811.

72. Rani, V.; Singh, H. B.; Butcher, R. J.; Organometallics 2017, 36,4741 .

73. Haghverdi, M.; Tadjarodi, A.; Bahri-laleh, N.; Nekoomanesh Haghighi, M.; J. Coord. Chem. 2017, 70, 1800.

74. Mol, G. P. S.; Aruldhas, D.; Hubert Joe, I.; Balachandran, S.; Anuf, A. R.; George, J.; J. Mol. Struct. 2019, 1176, 226.

75. Salman, A. W.; Rehman, G. U.; Abdullah, N.; Budagumpi, S.; Endud, S.; Abdallah, H. H.; Inorg. Chim. Acta 2015, 438, 14.

76. Li, S.; Li, Y.; Inorg. Chem. Commun. 2011, 14, 683.

77. Karaoğlu, K.; Emirik, M.; Menteşe, E.; Zengin, A.; Serbest, K.; Polyhedron 2016, 111, 109.

78. El Foujji, L.; El Bourakadi, K.; Mekhzoum, M. E. M.; Essassi, E. M.; Boeré, R. T.; Qaiss, A. E. K.; Bouhfid, R.; J. Mol. Struct. 2020, 1209, 127939.

79. Ge, Z.; Hayakawa, T.; Ando, S.; Ueda, M.; Akiike, T.; Miyamoto, H.; Kajita, T.; Kakimoto, M.; Adv. Funct. Mater. 2008, 18,584 .

80. El Bourakadi, K.; Mekhzoum, M. E. M.; Boeré, R. T.; Qaiss, A. E. K.; Bouhfid, R.; J. Mol. Struct. 2020, 1202, 127253.

81. Miranda, F. S.; Menezes, F. G.; Vicente, J.; Bortoluzzi, A. J.; Zucco, C.; Neves, A.; Gonçalves, N. S.; J. Mol. Struct. 2009, 938, 1.

82. Politzer, P.; Laurence, P. R.; Jayasuriya, K.; Environ. Health Perspect. 1985, 61, 191.

83. Murray, J. S.; Politzer, P.; Wiley Interdiscip. Rev.: Comput. Mol. Sci. 2011, 1, 153.

84. Popelier, P. L. A.; J. Phys. Chem. A 1998, 102, 1873.

85. Lipkowski, P.; Grabowski, S. J.; Robinson, T. L.; Leszczynski, J.; J. Phys. Chem. A 2004, 108, 10865.

86. Yu, W.; Lin, Z.; Huang, Z.; ChemPhysChem 2006, 7, 828.

87. Calhorda, M. J.; Lopes, P. E.; J. Organomet. Chem. 2000, 609, 53.

88. de Almeida, L. R.; Carvalho, P. S.; Napolitano, H. B.; Oliveira, S. S.; Camargo, A. J.; Figueredo, A. S.; de Aquino, G. L. B.; Carvalho-Silva, V. H.; Cryst. Growth Des. 2017, 17, 5145.

89. Vashchenko, A. V.; Afonin, A. V.; J. Struct. Chem. 2014, 55, 636.

90. Koch, U.; Popelier, P. L. A.; J. Phys. Chem. 1995, 99, 9747. 
91. Yurenko, Y. P.; Zhurakivsky, R. O.; Samijlenko, S. P.; Hovorun, D. M.; J. Biomol. Struct. Dyn. 2011, 29, 51.

92. Wojtulewski, S.; Grabowski, S. J.; Chem. Phys. 2005, 309, 183. 93. Baryshnikov, G. V.; Minaev, B. F.; Minaeva, V. A.; Baryshnikova, A. T.; Pittelkow, M.; J. Mol. Struct. 2012, 1026, 127.

94. Ośmiałowski, B.; J. Mol. Model. 2014, 20, 2356.

95. Nikolaienko, T. Y.; Bulavin, L. A.; Hovorun, D. M.; Phys. Chem. Chem. Phys. 2012, 14, 7441.

96. Vener, M. V.; Manaev, A. V.; Egorova, A. N.; Tsirelson, V. G.; J. Phys. Chem. A 2007, 111, 1155.

97. Gatti, C.; Saunders, V. R.; Roetti, C.; J. Chem. Phys. 1994, 101, 10686.

98. Grabowski, S. J.; J. Phys. Chem. A 2012, 116, 1838.

99. Syzgantseva, O. A.; Tognetti, V.; Joubert, L.; J. Phys. Chem. A 2013, 117, 8969.

100. Amezaga, N. J. M.; Pamies, S. C.; Peruchena, N. M.; Sosa, G. L.; J. Phys. Chem. A 2010, 114, 552.

101. Esrafili, M. D.; J. Mol. Model. 2012, 18, 5005.

102. Wang, Y.-H.; Zou, J.-W.; Lu, Y.-X.; Yu, Q.-S.; Xu, H.-Y.; Int. J. Quantum Chem. 2007, 107, 501.

103. Esrafili, M. D.; Hadipour, N. L.; Mol. Phys. 2011, 109, 2451.

104. Jabłoński, M.; Palusiak, M.; J. Phys. Chem. A 2012, 116, 2322.

105. Metrangolo, P.; Resnati, G.; Chem.- Eur. J. 2001, 7, 2511.

106. Dom, J. J. J.; Michielsen, B.; Maes, B. U. W.; Herrebout, W. A.; van der Veken, B. J.; Chem. Phys. Lett. 2009, 469, 85.

107. Mohan, N.; Vijayalakshmi, K. P.; Koga, N.; Suresh, C. H.; J. Comput. Chem. 2010, 31, 2874.

108. Grabowski, S. J.; Lipkowski, P.; J. Phys. Chem. A 2011, 115, 4765.
109. Iwaoka, M.; Komatsu, H.; Katsuda, T.; Tomoda, S.; J. Am. Chem. Soc. 2004, 126, 5309.

110. Sarma, B. K.; Mugesh, G.; ChemPhysChem 2009, 10, 3013.

111. Li, F.; Zheng, Z.; Zhang, G.; Xia, S.; Yu, L.; Spectrochim. Acta, Part A 2020, 228, 117689.

112. Shi, W.; Ren, F.; Phys. Chem. Chem. Phys. 2019, 21, 11871.

113. Al-Wahaibi, L. H.; Akilandeswari, G.; Anusha, R.; Al-Shaalan, N. H.; Alkmali, O. M.; El-Emam, A. A.; Percino, J. M.; Thamotharan, S.; J. Mol. Struct. 2019, 1183, 331.

114. Al-Wahaibi, L. H.; Sujay, S.; Muthu, G. G.; El-Emam, A. A.; Venkataramanan, N. S.; Al-Omary, F. A. M.; Ghabbour, H. A.; Percino, J.; Thamotharan, S.; J. Mol. Struct. 2018, 1159, 233.

115. Setifi, Z.; Cubillán, N.; Glidewell, C.; Nayak, S. K.; MoralesToyo, M.; Khajavian, R.; Setifi, F.; Mirzaei, M.; J. Mol. Struct. 2021, 1228, 129438.

116. Oliveira, B. G.; Struct. Chem. 2014, 25, 745.

117. Carroll, M. T.; Bader, R. F. W.; Mol. Phys. 1988, 65, 695.

118. Rozas, I.; Alkorta, I.; Elguero, J.; J. Am. Chem. Soc. 2000, 122, 11154.

119. López, C. S.; Faza, O. N.; Cossío, F. P.; York, D. M.; de Lera, A. R.; Chem. - Eur. J. 2005, 11, 1734.

120. Tarte, N. H.; Cho, H. Y.; Woo, S. I.; Macromolecules 2007, 40, 8162 .

121. Chowdhury, S.; Bhattacharya, A.; Saha, P.; Majumder, S.; Suresh, E.; Naskar, J. P.; J. Coord. Chem. 2016, 69, 3664.

Submitted: June 23, 2021

Published online: November 10, 2021 